\title{
An Investigation of the Listening Comprehension Strategies Used by Iranian EFL Learners
}

\author{
Samira Aliakbari Mianmahaleh \\ English Department, Rasht Branch, Islamic Azad University \\ Guilan, Iran \\ E-mail: samiira.aliakbari@gmail.com \\ RaminRahimy (Corresponding author) \\ English Department, Rasht Branch, Islamic Azad University \\ Guilan, Iran \\ E-mail: rahimy49@yahoo.com
}

Received: 22-07-2014

doi:10.7575/aiac.ijalel.v.4n.1p.255
Accepted: 16-09-2014

Published: 01-01-2015

URL: http://dx.doi.org/10.7575/aiac.ijalel.v.4n.1p.255

\begin{abstract}
The main goal of this investigation was to identify the listening strategies of Iranian male and female foreign (English) language learners and to compare the listening strategies of both groups of research participants. A total number of 120 Iranian male and female EFL learners at Payam-e-Nour university sat for an OPT test so as to make a homogenous group. Then 76 participants were selected according to OPT criteria to sit for Cheng's listening strategy questionnaire (2002) with subscales of " Metacognitive , "cognitive", and " Socio-affective" strategies in the Likert-scale format. After gathering the data multiple statistical tests were run. The result indicated that Iranian EFL learners used more metacognitive strategies than cognitive and socio-affective strategies respectively and gender influenced selecting the types of strategies for listening.

Keywords: Learning Strategies, Listening Strategies, Metacognitive Strategies, Cognitive Strategies, Socio-affective Strategies

\section{Introduction}

Listening has become an important part of many second or foreign language (L2) programs, as both it is a means to access various sources of knowledge and it is a criterion to determine whether an EFL learner is a competent language performancer or not. Teachers can help students improve their listening competence by equipping them with effective listening strategies and skills. In fact, its importance is influenced by the overwhelming amount of listening input in everyday life.

Despite its importance, listening is not an easy skill to master, especially listening in ESL or EFL contexts. Teachers look for the methods to find a way to enhance listening profeciency. Researchers and educaters know that learning strategies are necessary for EFL learners to be a successsful one. Many reseachers have investigated on learning strategies to find which strategieas can improve learning and especially listening skill.

Chamot (2005) believes that learning strategies are the thoughts and actions that individuals use to accomplish a learning goal. A lot of investigations in 1970s show the importance of learning strategies. The results mention that learners' own creative and active participation play an important role in their success in spite of having much aptitude and motivation.
\end{abstract}

\section{Review of Literature}

Listening comprehension is the most forgotten skills in second language learning, because the listening was paid the least attention of the four language skills. This neglect gets the fact that the teachers do not spend more time on students' listening and look for ways of improving students' listening skills. Unfortunately, it is supposed that listening comprehension is a passive activity, but on the contrary, it is an active process because people cannot develop oral skills if the speaker is not understood by the listener. listening is a process by which listeners share their mutual beliefs, the listeners must understand vocabularies and grammatical structures to interpret the meaning of language input from the text in their mind in which the communication take place, because communication is not only related to being able to speak, but also with understanding by the listener and then be able to produce output.

Several studies show that listening skill is important in language learning process, Such as (Holden, 2004, p. 257) states that listening has many aspects that it is difficult to deal with and understand so it requires a lot mental process, and all of these skills play an important role in the process of language learning and the improving more related language skills. So, having knowledge and the use of strategies in listening comprehension can help learners to take what they hear and organizing it into verbal units to which can apply meaning. It is seem from the strategies use by learners that the strategies develop learners' evaluation through learner's selection of their goals, help them in their learning, supervise their developing of learning, and evaluate their learning results. 
O'Malley and Chamot $(1990,1985)$ point out language learning strategies are divided into three main categories, metacognitive, cognitive, and social affective. It should be mentioned that although there are many researches in strategies (Griffith, 2004), but they are just different in the names and in classification that different researchers used them but not in their nature. And there are some learner's differences which affect their language learning and their choice of strategies (Azumi, 2008; Martinez, 1996). Learning strategies are "the specific thoughts and behaviors that individuals use to help them comprehend, learn, or retain new information" (O'Malley \& Chamot, 1990).

O'Malley and Chamot (1990) point out the importance of the strategies used by learners in the language learning process and an accompanying classification strategies in language learning and teaching. They have categorized two main types of strategies, metacognitive and cognitive strategies. Metacognitive strategies are important because they are the self-awareness of learners to their own language learning process. These strategies implicate thinking about the learning process; include planning their learning, monitoring their own comprehension, and evaluating the outcomes of their own learning. However, without the deployment of appropriate cognitive strategies are strategies that enable learners to encode the input and produce output by many different ways in language. Cognitive strategies are directly related to learning tasks and are used by learners when they mentally and or physically manipulate material to be learned, or when they apply a specific technique to a learning task. A third category that is socio-affective strategies that happens when language learners interact with each other to clarify a confusing point, question the teacher for clarification, to solve problems when they participate in a group discussion or cooperative learning group, or apply specific techniques to lower their anxiety level.

See Vandergrift (1997) for listening strategies definition and examples in each of the three strategy categories. Although, in recent years there are extremely second language strategy research, the number of studies in listening comprehension is comparatively small, and even the research in listening strategies is more limited (Rubin 1994). Furthermore, the few studies suggest that the teacher can instruct in strategy use to improve their students' performance on listening tasks. In addition research has pointed to the powerful role of listening strategies in learning, and potentially use of metacognitive strategies in listening tasks. Mendelsohn (1994) suggested that the teacher should do well to create an awareness of metacognitive strategies in developing the performance of their students, and particularly to improve their listening in oral texts to deal with getting information and complete a comprehension task. Rubin claimed that "the combination of well selected video and the acquisition of effective learning strategies can improve student affect and motivation" (p. 32). Since 1980, there have been a many studylooked into the listening comprehension strategies used by L2/FL learners. With regard to ESL listening, Conrad (1985) found that as L2 listeners increased in proficiency they relied less on syntactic or phonological cues than contextual semantic cues.

\section{Statement of the problem}

For language learning, all the basic language skills -reading, writing, speaking and listening- are of great importance to be able to use the language effectively. Among these skills, listening is a crucial skill for language learners because without understanding the spoken language, problems in communication arise. For effective communication comprehending the message is vital.

Listening cannot be considered separately from any language learning process. It would be impossible to learn a language without listening. The important role of listening has been emphasized in different parts of in language teaching. Thus purpose of this study is to look into the males and females student's preferences for strategies in listening tasks. In addition the influence of gender on selecting the listening strategies will help practitioners, EFL teachers and syllabus designers especially in Iran with separated male and female EFL classrooms.

In Iran, the learners of foreign language mostly do not feel strength in listening. They are always concerned about lack of understanding the native speakers in real situation, in movies or while listening to authentic news through radio" Hatch \&Faraday (2008). By the way in Iran male and female sit in separated classroom to learn English, in the case there is influential relationship between genders and selecting listening strategies the EFL teachers can benefit from the results of this study to have more useful outcome.

\section{Research questions and hypotheses}

Regarding the important effect of listening and the related strategies in second language, the following questions are formulated:

Q1: What listening comprehension strategies do Iranian EFL students use at intermediate level?

Q2: Are there any significant differences between male and female EFL students in using listening comprehension strategies at intermediate level?

Regarding the important effect of listening and the related strategies in second language, the following hypothesis is formulated:

H0: there are not any significant differences between male and female EFL students in using listening comprehension strategies.

\section{Methodology}

\subsection{Participants}

The participants of the current study contained 76 Iranian intermediate EFL learners who were selected through administrating an OPT from among a group of 120 EFL learners studying in Payam-e-Nour university in Guilan province that present English. These 120 EFL learners who were mostly female selected. All the participants were undergraduate students of either English and literature or English translation (freshmen, sophomores, juniors, and 
seniors) they were in different age from 18 to 35 male and female. The age and mother tongue weren't considered as influential variables. Furthermore, no learning disability was observed among the subjects.

5.2 Instruments

Two different instruments were used to collect the data in the present study:

1) Oxford Placement Test (Allan, 2004) which is a standardized test of Oxford University to determine EFL learners' proficiency level and make the participants homogenized.

2) A listening comprehension strategies questionnaire which was adapted from

Cheng, C. (2002).

By the way the questionnaire was written in English and no translation of them used.

\subsection{Procedure}

In order to select the required participants at intermediate level of proficiency, 120 students from Payam-e-Nour university were tested through administering the OPT (Oxford Placement Test). Then, Seventy-six students whose scored were $31+$ in grammar and vocabulary and $8+$ in reading section were selected as the main sample for the present study, 38 females and 38 males and their age range was between 18 and 35 .

Seventy-six bachelors EFL learners (38female and 38 male) were selected based on the results of the OPT test. Cheng's listening comprehension strategies questionnaire was implemented. Cronbach's Alpha statistic was computed for the 30 questionnaire items and a reliability of .79 was obtained. The data gathered through the questionnaire were analyzed through the use of Statistical Package for Social Sciences (SPSS).

\subsection{Data Analysis}

In the analysis phase of this study, the results obtained from the questionnaire were summed up and the procedures of descriptive statistics (including frequencies, means, standard deviations, etc.) were conducted on them. Mann Whitney $\mathrm{U}$ Test was then run in order to find out if there was any significant difference between female and male EFL learners' listening comprehension strategies. Both descriptive and differential statistics were incorporated in this study through the use of Statistical Package for Social Sciences (SPSS).

\section{Results}

The first research question concerned with different types and amount of listening comprehension strategies that was used by the participants. The questionnaire had three categories including metacognitive, cognitive, and socio- affective strategies. The means and standard deviations were computed for each category of the questionnaire. Besides, the total mean and total standard deviation was also calculated. The results of the descriptive statistics are presented in the following table:

Table1. Statistics for different categories of the questionnaire

\begin{tabular}{|c|c|c|c|c|c|}
\hline \multicolumn{6}{|c|}{ Statistics } \\
\hline & \multicolumn{2}{|c|}{$\mathrm{N}$} & \multirow[t]{2}{*}{ Mean } & \multirow[t]{2}{*}{ Std. Deviation } & \multirow[t]{2}{*}{ Sum } \\
\hline & Valid & Missing & & & \\
\hline gender & 76 & 0 & 1.5000 & .50332 & 114.00 \\
\hline Metacognitive strategies & 76 & 0 & 2.8026 & .31154 & 213.00 \\
\hline Pre-listening activities & 76 & 0 & 3.1140 & .36333 & 236.67 \\
\hline While-listening activities & 76 & 0 & 2.6809 & .35261 & 203.75 \\
\hline Post-listening activities & 76 & 0 & 2.6535 & .60477 & 201.67 \\
\hline Cognitive strategies & 76 & 0 & 2.7217 & .21792 & 206.85 \\
\hline CognitiveFormalPracticingStrategies & 76 & 0 & 2.6053 & .39893 & 198.00 \\
\hline Bottom-up strategies & 76 & 0 & 2.3717 & .40516 & 180.25 \\
\hline Top-down strategies & 76 & 0 & 3.0132 & .25205 & 229.00 \\
\hline Socio-affective strategies & 76 & 0 & 2.7350 & .32635 & 207.86 \\
\hline Total listening comprehension strategy & 76 & 0 & 2.7518 & .19055 & 209.13 \\
\hline
\end{tabular}

The second research question aimed to find out whether these differences between males and females were statically significant. The subsequent section concerns the second research question.

Table2. Mann-Whitney U Test for the listening comprehension strategy-use of males and females

\begin{tabular}{|c|c|}
\hline \multicolumn{2}{|c|}{ Test Statistics $^{\mathrm{a}}$} \\
\hline & n strategy \\
\hline Mann-Whitney U & 417.000 \\
\hline Wilcoxon W & 1158.000 \\
\hline $\mathrm{Z}$ & -3.179 \\
\hline Asymp. Sig. (2-tailed) & .001 \\
\hline
\end{tabular}


The Mann-Whitney U Test revealed significant difference in the use of listening comprehension strategies of males $(M d=2.70, n=38)$ and females $(M d=2.80, n=38)$, (Mann Whitney $U=417.000, z=-3.179, p=.001, r=.36)$. This rejected the null hypothesis and suggested that there were significant differences between male and female EFL students in using listening comprehension strategies.

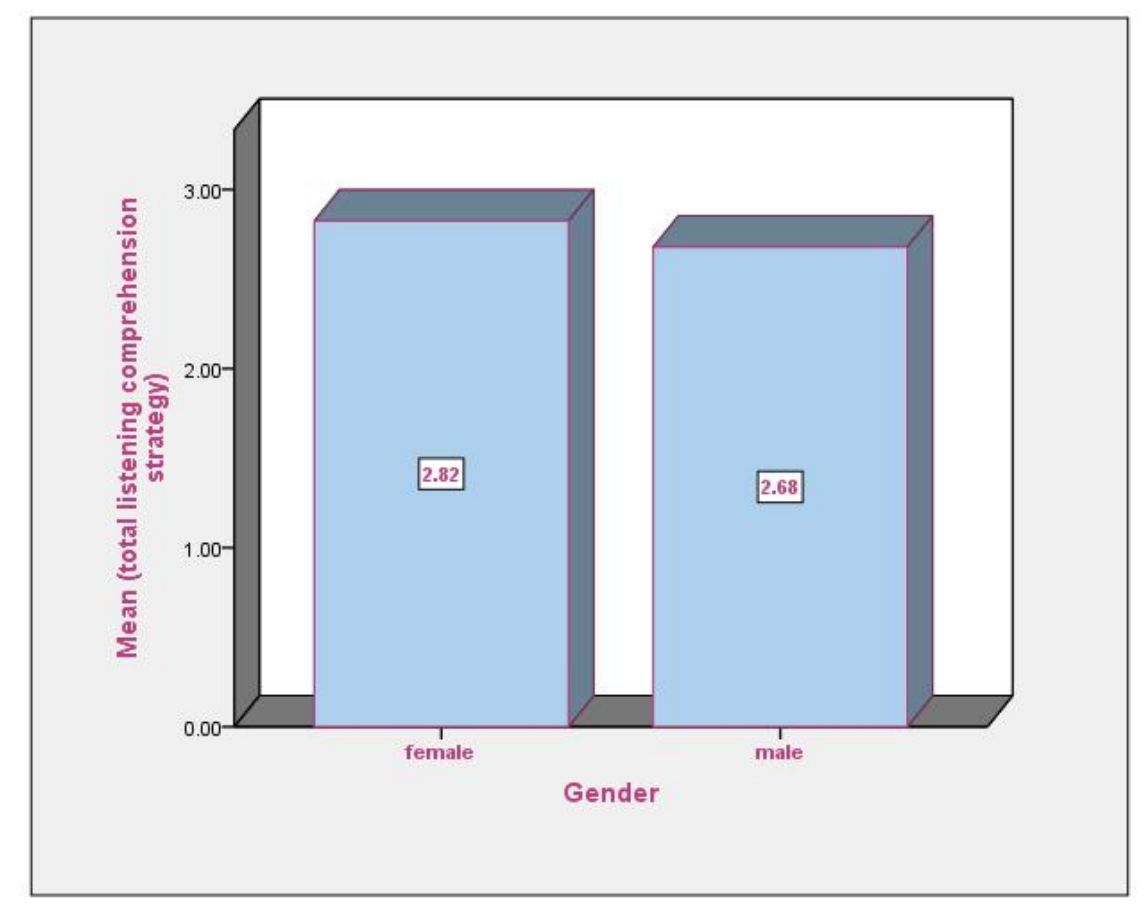

Figure1. The comparison between males and females in their use of listening comprehension strategies

The results revealed female participants made higher uses of these strategies and the difference between males and females was statistically significant in this regard $(\mathrm{p} \leq .05)$.

\section{Discussion}

The data of this study clearly show that the participants had a substantial awareness and control of their metacognitive activities and then cognitive and socio-affective strategies respectively. The information provided by the participants demonstrated that EFL listening was a complex process in which they consciously invoked a repertoire of metacognitive strategies. They used these strategies to planning, monitoring, evaluating, and modifying their comprehension while listening. This study is significant because a detailed account of the metacognitive strategies employed by the participants in listening comprehension task.

Considering the gender factor and its effect in choosing listening strategies, it is concluded that female participants had higher mean rank (46.53) than male ones (30.47) in selecting and using of listening strategies. Respecting the data gathered, the median of female group (2.80) is higher than the median of males (2.70) and regarding $\mathrm{p}$ value $(\mathrm{p}=0.001)$ and $\mathrm{r}=0.36$ the null hypothesis which said that there is no relationship between gender as factor on choosing listening strategies is rejected. In other words, there is a significant relation between the gender of the participants and their use of English listening strategies.

This finding implies that the difference in using listening strategies between male and female listeners seems to be related to the quantities of listening strategies they employed. Each use of listening strategy is not necessarily successful or efficient, but it represents the listener's ability of actively solving problems.

In the current study, results indicate high use of metacognitive strategies and low use of socio-affective strategies; this results support Goh and Kwah (1997) which revealed that students regularly employ metacognitive strategies in language learning and rarely utilize socio-affective strategies. The previous research studies have shown a consistent perspective that language learners tend not to use socio-affective strategies in language learning. In addition to evidence on strategy instruction presented in section 2, research has pointed to the powerful role of metacognition in learning, and the potential for greater use of metacognitive strategies (Vandergrift 1997).

\section{Conclusion}

An emphasis on listening comprehension and application of listening strategies will help Iranian students for promoting English ability on the language input they receive, and they can achieve greater success in language learning. Listening strategies are useful tools for students because they create more dependable and less thwart to language learning success. Particularly, the use of listening strategies can make authentic texts more approachable in the beginning level of learning a language, so that the process can make interesting for the learners. This should be noted that the process of developing useful listening strategies is best accomplish when teachers provide students with sufficient listening practice without evaluation. Too often Iranian teachers only use listening activities to test the listening abilities of their 
students, which lead to bear much anxiety and pressure while listening. This is not a context encouraging to the achievement of useful listening strategies.

This paper has argued that there are cognitive, metacognitive and socio-affective strategies that try to take more advantages and focusing on listening in language learning and teaching, these strategies are crucial to success in listening comprehension for students, and that these strategies can be taught by teachers. Finally, this paper has provided a framework for instruction into L2 classes at systems in which students of males and females are not educated together, it is obvious that these strategies can be considered as an effective approach to accelerate Iranian learner's listening competence as well as their learning motivation.

\section{References}

Anserson, J. R. (1981). Cognitive skills and their acquisition. Hillsdale, NJ: LawernceErlbaun

Bacon, S. M. (1992). The relationship between gender, comprehension, processing strategies, and cognitive and affective response in foreign language listening. The modern language Journal, 76(2), 160-178.

Bialystock, E.ole of conscious strategies in second language proficiency. Modern language Journal, 65, 13-24. Brown, H.D. (2000). Principles of language learning and teaching (4 ${ }^{\text {th }}$ ed.).New York: Addison Wesley Longman, Inc

Brownell, J. (1995). Listening: attitudes, principles, and skills. The United States of America: Allyn \& Bacon.

Chamot, A. U., \& Kupper, L. (1989). Learning strategies in foreign language instruction. ForeignLanguage Annals, 22 , 13-24.

Cheng, C. (2002). Effects on Listening Strategy Instruction on Junior High School Students. TheEleventh International Symposium on English Teaching/Fourth Pan Asian Conference.

Cohen, A. D., \& Dornyei, Z. (2002). Focus on the language learner: Motivation, styles, and strategies. In N.Scmitt (Ed.), Anintroduction to applied linguistics (pp.179-190). Edward Arnold Publishers comprehension. Unpublished master's thesis, National Cheng Kung University, Tainan. Corporation.

Dornyei, Z. (2005). The psychology of the language learner: individual defferences in second language acquisition. Lawrence Erlbaum, Mahwah, New Jersey.

Freire, P. (1970). The adult literacy process as cultural action for freedon. Harvard Educational Review, 40, $205-224$.

Freire, P. (1997). Pedagogy of heart. New York: Continuum Press.

Freire, P. (1993). Pedagogy of the city. New York: Continuum Press.

Freire, P. (1998). Cultural action and conscientization.Harvard educational Review, 68 (4)

Freire, P. \& Macado, D. (1987). Literacy: Reading the word and the world: London: routledge \& Kegan Press.

Goh.C. (2000). Acognitiveperpectiveonlanguage learners' listening comprehension problems. System, $28,55-75$.

Hatch, E. \& Farhady H. (1982). Research design and statistics for applied linguistics. Rowley: Newbury House Publishers.

Krashen, S D. (1984), Principle and Practice in Second Language Acquisition. Oxford: Pergamon Press.

Lynch, T. (1988). Listening. Oxford: Oxford University Press Macaro, E. (2006). Strategies for language learning and for language use: revising theoretical framework. Modern Language Journal, 90, 320-337.

O’Malley, j. m., \& Chamot, A. U. (1990). Learning strategies in second language acquisition. Cambridge: Cambridge University Press.

O’Malley, J. M., \& Chamot, A. U. (1990). Learning strategies in second languageacquisition.Cambridge, England: Ca mbridge University Press.

Oxford, R. (19936). Research update on L2 listening. System, 21,205-211.

Oxford, R. L. (1989). Language learning strategies. N.Y: Newbury House

Oxford, R., \& Cohen, A. (1992). Language learning strategies learning strategies: Crucial issues of concept and classification. Applied language Learning, 3/1 and 3/2:1-35.

Ozeki, N. (2000). Listening strategy instruction for female EFL college students in Japan. Unpublished PhD dissertation, Indiana University of Pennsylvania.

Politzer, R., \& McGroarty, M. (1985).An exploration study of learning behaviors and their relation to gains in linguistic and communicative competence. TESOL Quarterly, 19,103-124.

Purpura, J.E. (1997). An analysis of the relationship between test takers cognitive and metacognitive strategy use and second language test performance language learning, 47,289-325.

Richards, J.C., \& Rodgers, T. S. (2001). Approaches and Methods in Language Teaching. (Second Edition). USA: Cambridge University Press. 
Richards, J.C., \& Schmidt, R. (2002). Longman Dictionary of Language Teaching and Applied Linguistics. Pearson Education: Longman.

Rost, M., \& Ross, S. (1991). Learner use of strategies in interaction: Typology and strategies. Cambridge University Press.

Scarcella, R. \& Oxford, R., (1992), The Tapestry of Language Learning: The Individual in the Communicative Classroom. Boston: Heinle \& Heinle.

Skehan, P. (1989) Progress in language testing: the 1990s. In J.C. Alderson (ED.), Language testing in the 1990s: the communicative Legacy (pp.3-20). London: Macmillan.

Vandergrift, L. (1997). The comprehension strategies of second language (French) listeners: A descriptive study. Foreign Language Annals, 30(3), 387 409.

Vandergrift, L. (2003). Orchestrating strategy use: Towards a model of the skilled L2 listener. Language learning, 53, 461- 491.

Vandergrift, L. (2004). Second language listening: listening ability proficiency. The Modern Language Journal 90, 6-18

Watson, G. B., \& Glaser, E. M. (1980). WGCTA WatsonGlaser critical thinking appraisal manual: Forms $A$ and Quarterly, 31(1), 72-95. 